\title{
Functional and sensory properties of olives fortified spreadable cheese
}

\author{
Maja Repajić, Anamarija Grudenić, Branka Levaj
}

\begin{abstract}
University of Zagreb, Faculty of Food Technology and Biotechnology, Laboratory for Technology of Fruits and Vegetables Preservation and Processing, Pierottijeva 6, 10000 Zagreb, Croatia

${ }^{*}$ Corresponding author: E-mail: mrepajic@pbf.hr; Phone: +3851 4605036
\end{abstract}

\section{Abstract}

The aim of this work was to investigate the influence of olive type (green and black) and content on quality and sensory properties of spreadable cheese with olives. Total solids, pH value, colour (colourimetric), total phenols by Folin-Ciocalteau method and antioxidant capacity (FRAP) of the raw materials as well as of the prepared samples were examined. Furthermore, samples of spreadable cheese with olives were sensory evaluated using the Quantitative Descriptive Analysis (QDA). ANOVA showed that the applied sources of variation significantly affected the majority of investigated parameters. Samples with black olives had slightly higher dry matter content and pH value, and were characterized by darker and dull colour. The determined total phenols contents and antioxidant capacity showed a good potential of spreadable cheese with olives as a functional food, whereby green olives samples had higher total phenols content as well as antioxidant capacity. Generally, sensory properties of all samples were very well scored, indicating their good acceptability by consumers. Samples with black olives accomplished higher scores for flavour harmony and overall acceptability, where spreadable cheese with the highest olive content emphasized with the highest scores for these properties.

Key words: spreadable cheese, olives, quality, phenols, sensory attributes

\section{Introduction}

Cheese is a widely popular dairy product consumed almost on a daily basis. It basically represents a solid milk concentrate, mainly consisting of proteins and fats (Han et al., 2011). Among numerous cheese types, fresh cheese refers to a type of cheese produced by the coagulation of milk, cream or whey via acidification or a combination of acid and heat and is ready for consumption after completing the manufacturing operations (Guinee et al., 1993). Based on the applied pro- cedure, fresh cheese can be further processed into various fresh cheese-based products such as fresh cheese spreads, which are frequently consumed milk-based commodities.

Due to increased health awareness of modern consumers, fortification of dairy foods, including fresh cheese spreads, with bioactive compounds from natural plant sources is desirable. The main bioactive constituents of plants, fruit and vegetable are polyphenols which represent a wide group of compounds with scavenging free radicals activity and thus strong antioxidants, therefore providing 
many beneficial health effects (Han et al., 2007; Cutrim and Cortez, 2018). Dairy products possess a certain antioxidant activity that is mostly derived from milk proteins, primarily caseins (Fardet and Rock, 2018), and various cheese types have been documented as a good sources of bioactive peptides (Gupta et al., 2009; Korhonen, 2009; Revilla et al., 2016; Barać et al., 2017). Implementation of various plant, fruit and vegetable-based materials could be a good solution to additionally increase their antioxidant activity. Olives surely could represent a good choice for that purpose. Due to its valuable composition constituted of high contents of monosaturated fatty acids, fibres, minerals, vitamins, polyphenols and triterpenic acid compounds (Romero et al., 2002, 2004, 2010; García et al., 2018), olives provide numerous health advantages (Pérez-López et al., 2009; Frisardi et al., 2010; Estruch et al., 2013; Féart et al., 2013). Those bioactive compounds are also accountable for olives sensory properties, bitterness namely, which originates mainly from oleuropein, the most predominant olive's polyphenol. In order to reduce its bitterness, olives are cured in several possible preparation types for debittering and obtaining the edible product, i.e., table olives (Johnson and Mitchell, 2018).

Table olives composition can vary due to many pre-harvest factors, e.g., cultivar type (Durante et al., 2018; García et al., 2018), maturity stage (Othman et al., 2009; Ghorbal et al., 2018) and environmental conditions (Ghorbal et al., 2018). Furthermore, considering the applied preparation procedure, table olives qualitatively and quantitatively differ in polyphenols composition (García et al., 2018), which consequently affect its bioactive and sensory properties. For example, lye debittered olives showed deficiency of polyphenol contents compared to unprocessed ones or naturally fermented (Romero et al., 2004; Marsilio et al., 2005; Alexandraki et al., 2014; Johnson et al., 2018). At the same time they were sensory evaluated as less bitter, less firmed and less crispy (Marsilio et al., 2005). Hence, table olives' chemical, textural and sensorial characteristics considerably depend on the selection of cultivar, harvest stage and processing technology.

Along with high valuable nutritional properties, consumers also demand sensorially suitable food product. Accordingly, it is important to properly examine and evaluate sensory characteristics of particular product in order to recognize its advantages or possible disadvantages, thus pointing to its improvement and thereby achieving the satisfying desirability.

Therefore, the aim of this study was to produce spreadable cheese fortified with olives and to investigate the influence of black and green olives addition, as well as their various contents on its quality, functional and sensory properties.

\section{Materials and methods}

\section{Sample preparation}

For the preparation of the spreadable cheese with olives samples (SCO), fresh semi-fat cheese (up to $25 \%$ of milk fat in dry matter) (FC) and unpitted table black (B) and green (G) olives were purchased from the local market (Croatia). Amount of $100 \mathrm{~g}$ of FC was homogenized with kitchen hand blender ProMix HR1623/00 (Royal Philips, Amsterdam, Netherland) with the following contents of drained and chopped olives: $10 \mathrm{~g}$ (B10, G10), $30 \mathrm{~g}$ (B30, G30) and $50 \mathrm{~g}$ (B50, G50). Prepared samples (300 g) were stored in sealed sterilized glass jars at $+4{ }^{\circ} \mathrm{C}$. Prior analysis, samples were kept at ambient temperature for $1 \mathrm{~h}$.

\section{Determination of the total solids and $\mathrm{pH}$ value}

Total solids (TS) were determined gravimetrically by drying the samples at $105^{\circ} \mathrm{C}$ until reaching constant mass (AOAC, 1990) and $\mathrm{pH}$ value was measured using a pH-meter SevenEasy S20 (Mettler Toledo GmbH, Zurich, Switzerland). All measurements were done in triplicate $(n=3)$ and results are expressed as the mean value \pm SD.

\section{Colour measurement}

CIELab colour space (CIE, 1976) was applied for the colour analysis, where reflectance colour measurements were performed by Konica Minolta CM-5 spectrophotometer (Konica Minolta Sensing, Inc., Osaka, Japan). Before the measurement, in- 
strument was calibrated with a standard black and white according to the manufacturer's instructions. Samples were situated in a glass petri dish provided with the instrument and values of $L^{*}$ (lightness), $a^{*}$ (redness/greenness) and $b^{*}$ (yellowness/blueness) were triple $(n=3)$ recorded for D65 illuminant with $2^{\circ}$ standard angle. Furthermore, $C^{*}$ (chroma), $H^{\circ}$ (hue angle) and $\Delta \mathrm{E}^{*}$ ab (total colour difference) were calculated using following equations:

$$
\begin{aligned}
& \mathrm{C}^{*}=\sqrt{\left(\mathrm{a}^{* 2}+\mathrm{b}^{* 2}\right)} \\
& \mathrm{H}^{\circ}=\operatorname{arctg}\left(\frac{\mathrm{b}^{*}}{\mathrm{a}^{*}}\right) \\
& \Delta \mathrm{E}_{\mathrm{ab}}^{*}=\sqrt{\left(\Delta \mathrm{L}^{* 2}+\Delta \mathrm{a}^{* 2}+\Delta \mathrm{b}^{* 2}\right.}
\end{aligned}
$$

where all $\Delta \mathrm{L}^{* 2}, \Delta \mathrm{a}^{* 2}, \Delta \mathrm{b}^{* 2}$ were calculated in reference to FC. Colour data are presented as mean value \pm SD.

\section{Determination of the total phenols and} antioxidant capacity

Extracts of FC, B, G and SCO were prepared according to modified method of Apostolidis et al. (2007). Briefly, $20 \mathrm{~g}$ of sample was ultrasonicated with $20 \mathrm{~mL}$ of an aqueous solution of ethanol (70 $\%, v / v$ ) in an ultrasound bath (Bandelin Electronic $\mathrm{GmbH} \&$ Co. KG, Berlin, Germany) at $50{ }^{\circ} \mathrm{C}$ for 30 minutes. The obtained extracts were centrifugated at 5500 rpm/20 minutes, decanted and filtered. Collected supernatants were used for total phenols (TP) and antioxidant capacity (AC) determination. Before the measurements, $B$ and $G$ extracts were fivefold and SCO twofold diluted, while FC was analysed without dilution.

The TP determination was carried out using Folin-Ciocalteau method (Shortle et al., 2014), as follows: $100 \mu \mathrm{L}$ of the sample, $200 \mu \mathrm{L}$ of Folin Ciocalteu's reagent, $2 \mathrm{~mL}$ of distilled water and 1 $\mathrm{mL}$ of sodium carbonate aqueous solution (20\%, $\mathrm{w} / \mathrm{v}$ ) were combined and incubated at $50{ }^{\circ} \mathrm{C}$ for 25 minutes. The absorbance was measured at $765 \mathrm{~nm}$ against the extraction solvent set as blank. Calculation of TP concentrations was based on the gallic acid (5 mg mL-1) calibration curve and TP were expressed as mg of gallic acid (GAE) equivalents per $100 \mathrm{~g}$ of fresh weight.

Ferrous reducing antioxidant power (FRAP) method (Benzie and Strain, 1996) used for the AC determination, was slightly modified: the mixture of $240 \mu \mathrm{L}$ of distilled water, $80 \mu \mathrm{L}$ of the sample and $2080 \mu \mathrm{L}$ of FRAP reagent [2.5 mL of 2,4,6-Tripyridyltriazine (TPTZ) solution (10 mM) in hydrochloric acid $(40 \mathrm{mM})$ mixed with $2.5 \mathrm{~mL}$ of iron (III) chloride solution (20 mM) and $25 \mathrm{~mL}$ of acetate buffer (0.3 M, pH=3.6)] was incubated for 5 min at $37^{\circ} \mathrm{C}$ before the absorbance was measured at $593 \mathrm{~nm}$ against the blank (ethanol, $70 \%$ ). The calibration curve was obtained using different concentrations of iron (II) sulfate heptahydrate solution (1

$\mathrm{mM})$ and $\mathrm{AC}$ was expressed as $\mu \mathrm{mol} \mathrm{Fe}^{2+}$ equivalents per $100 \mathrm{~g}$ of fresh weight.

All spectrophotometric assays were triple $(n=3)$ performed using UV-VIS spectrophotometer UV1600PC (VWR International, Radnor, USA) and the mean value $\pm S D$ was calculated.

\section{Sensory analysis}

The Quantitative Descriptive Analysis (QDA) was applied for SCO sensory evaluation, where following sensory properties attributed to SCO were examined: appearance, taste (saltiness, sourness, bitterness, off-taste), flavour (cheese flavour, olive flavour, flavour harmony), odour (cheese odour, olive odour, off-odour), spreadability and the overall acceptance (Lucera et al., 2018). The procedure was conducted by a trained group of thirteen people ( $n=13)$ (eight females and five males, 22-59 years old) using a 10-point scale ( $0=$ none, $10=$ extremely strong) in a sensory laboratory equipped according to ISO 8589 (2007). Prior to the sensory evaluation, panelists were trained in a $2 \mathrm{~h}$-session in order to familiarize with the product and to define the applied descriptors. Samples were served at room temperature in randomly ordered coded transparent plastic cups with associated plastic spoons. Obtained results are presented graphically in "spider net" as mean values.

\section{Statistical analysis}

In order to investigate the differences among raw materials in their physical and functional characteristics as well as the influence of olive type and olive content on physical, functional and sensory properties of SCO, analysis of variance (ANOVA) was performed and marginal means were com- 
pared by Tukey's HSD test. Furthermore, for the assessment of relationships among determined parameters of SCO samples, Pearson's correlation coefficient was calculated and possible grouping of the SCO by the applied conditions (olive type, olive content) was examined using the Principal Component Analysis (PCA) on the physical, functional and sensory analysis correlation matrix. All tests were carried out using a statistical software Statistica ver. 8.0 (Statsoft Inc., Tulsa, USA) at significance level $p \leq 0.05$.

\section{Results and discussion}

Objective of this study was to examine the influence of adding various contents of black and green olives to fresh cheese in order to obtain a spreadable cheese fortified with olives. Hence, the physical, functional and sensory properties of raw materials (FC, B, G) and obtained SCO samples were investigated. The determined TS and $\mathrm{pH}$ values of SCO raw materials are presented in Table 1 and are generally in accordance with previous research data (Romero et al., 2004; García et al., 2018; Lucera et al., 2018). TS of raw materials did not differ much (21.30-21.82\%), whereby the highest TS (21.82 \%) was associated to sample B. Statistical analysis showed significant influence $(p \leq 0.05)$ of the olive type and olive content on the TS content of SCO samples (Table 2). As for ol- ive types, TS of SCO with B (BSCO) were slightly higher compared to the SCO containing G (GSCO). Based on the olive content, increase in olive level resulted in a slight TS increase. Furthermore, $\mathrm{pH}$ value of FC was 4.43 , similar to the results published by Lucera et al. (2018), while olives showed larger differences. Sample B had a higher $\mathrm{pH}$ value (7.55), opposite to $G$ (3.63). The obtained results are comprehensible, since olives used in this study differentiated by its brine composition, whereby sample $G$ was stored in brine containing the citric acid and brine of B did not include acid. Our results corresponds to previous research of García et al. (2018) who documented a pH value between 7.0-7.2 in several black olive types and Panagou and Tassou (2006) who reported a pH of 4.2-4.3 in green Greek olives at the end of fermentation. The mentioned $\mathrm{pH}$ differences between olive types significantly $(\mathrm{p} \leq 0.05)$ affected the $\mathrm{SCO} \mathrm{pH}$ values, whereby all BSCO showed higher values, ranging from 4.46-4.67 (Table 2). The $\mathrm{pH}$ range in GSCO was 4.28-4.37. Although the olive content did not show a statistically significant influence on the $\mathrm{pH}$ values, an opposite trend in $\mathrm{pH}$ values among BSCO and GBSCO could be observed. With the increase of B levels in BSCO, pH values also increased, while $\mathrm{pH}$ values of GSCO decreased in the same conditions, what is in accordance with previously mentioned $\mathrm{pH}$ values of raw materials. The calculated correlation coefficients showed strong correlation between TS and $\mathrm{pH}$ value (Table 4).

TABLE 1. Total solids, pH value, colour parameters, total phenols and antioxidant capacity of fresh cheese (FC), black (B) and green (G) olives

\begin{tabular}{|c|c|c|c|c|c|c|c|c|c|}
\hline Samples & $\begin{array}{l}\text { TS } \\
(\%)\end{array}$ & $\begin{array}{r}\mathrm{pH} \\
\text { value }\end{array}$ & $L^{*}$ & $a^{*}$ & $\mathbf{b}^{*}$ & $C^{*}$ & $H^{\circ}$ & $\begin{array}{r}\mathrm{TP} \\
(\mathrm{mg} \mathrm{GAE} / \\
100 \mathrm{~g})\end{array}$ & $\begin{array}{r}\mathrm{AC} \\
\left(\mu \mathrm{mol} \mathrm{Fe} \mathrm{F}^{2+1}\right. \\
100 \mathrm{~g})\end{array}$ \\
\hline FC & $\begin{array}{r}21.30 \\
\pm 0.03^{a}\end{array}$ & $\begin{array}{r}4.43 \\
\pm 0.00^{\mathrm{b}}\end{array}$ & $\begin{array}{r}94.35 \\
\pm 0.01 c\end{array}$ & $\begin{array}{r}-1.05 \\
\pm 0.01^{a}\end{array}$ & $\begin{array}{r}10.02 \\
\pm 0.00^{\mathrm{b}}\end{array}$ & $\begin{array}{r}10.07 \\
\pm 0.00^{\mathrm{b}}\end{array}$ & $\begin{array}{r}95.95 \\
\pm 0.07 c\end{array}$ & $\begin{array}{r}5.84 \\
\pm 0.34^{\mathrm{a}}\end{array}$ & $\begin{array}{r}26.41 \\
\pm 1.06^{\mathrm{a}}\end{array}$ \\
\hline B & $\begin{array}{r}21.82 \\
\pm 0.17^{\mathrm{a}} \\
\end{array}$ & $\begin{array}{r}7.55 \\
\pm 0.00^{\circ} \\
\end{array}$ & $\begin{array}{r}19.55 \\
\pm 0.02^{\mathrm{a}} \\
\end{array}$ & $\begin{array}{r}3.70 \\
\pm 0.10^{\mathrm{b}} \\
\end{array}$ & $\begin{array}{r}6.30 \\
\pm 0.09^{a} \\
\end{array}$ & $\begin{array}{r}7.30 \\
\pm 0.07^{a} \\
\end{array}$ & $\begin{array}{r}59.53 \\
\pm 0.91^{\mathrm{a}} \\
\end{array}$ & $\begin{array}{r}14.78 \\
\pm 1.11^{\mathrm{b}}\end{array}$ & $\begin{array}{r}237.42 \\
\pm 17.88^{\mathrm{b}} \\
\end{array}$ \\
\hline G & $\begin{array}{r}21.34 \\
\pm 0.39^{\mathrm{a}}\end{array}$ & $\begin{array}{r}3.63 \\
\pm 0.00^{\mathrm{a}}\end{array}$ & $\begin{array}{r}57.61 \\
\pm 0.03^{b}\end{array}$ & $\begin{array}{r}4.12 \\
\pm 0.00^{c}\end{array}$ & $\begin{array}{c}34.73 \\
\pm 0.02^{c}\end{array}$ & $\begin{array}{r}34.98 \\
\pm 0.02^{c}\end{array}$ & $\begin{array}{r}83.24 \\
\pm 0.01^{\mathrm{b}}\end{array}$ & $\begin{array}{r}43.16 \\
\pm 1.61^{c}\end{array}$ & $\begin{array}{r}736.93 \\
\pm 34.34^{c}\end{array}$ \\
\hline
\end{tabular}

Different letters indicate significant difference between samples ( $p \leq 0.05)$. Results are expressed as mean value $\pm S D$. TS=total solids, TP=total phenols, $\mathrm{AC}=$ antioxidant capacity 
TABLE 2. Total solids, pH value and colour parameters of spreadable cheese with different content of black (B) and green (G) olives

\begin{tabular}{|c|c|c|c|c|c|c|c|c|}
\hline Samples & $\begin{array}{r}\text { TS } \\
(\%)\end{array}$ & $\begin{array}{r}\mathrm{pH} \\
\text { value }\end{array}$ & $L^{*}$ & $a^{*}$ & $b^{*}$ & $C^{*}$ & $H^{\circ}$ & $\Delta E_{a b}^{*}$ \\
\hline B10 & $\begin{array}{r}21.33 \\
\pm 0.27^{\mathrm{bA}} \\
\end{array}$ & $\begin{array}{r}4.46 \\
\pm 0.00^{\mathrm{bA}} \\
\end{array}$ & $\begin{array}{r}78.96 \\
\pm 0.01^{\mathrm{ac}} \\
\end{array}$ & $\begin{array}{r}1.21 \\
\pm 0.02^{\mathrm{bA}} \\
\end{array}$ & $\begin{array}{r}9.89 \\
\pm 0.00^{\mathrm{aA}} \\
\end{array}$ & $\begin{array}{r}9.97 \\
\pm 0.01^{\mathrm{aA}} \\
\end{array}$ & $\begin{array}{r}83.02 \\
\pm 0.08^{\mathrm{ac}} \\
\end{array}$ & $\begin{array}{r}15.56 \\
\pm 0.01^{\mathrm{bA}} \\
\end{array}$ \\
\hline B30 & $\begin{array}{r}21.39 \\
\pm 0.14^{\mathrm{bAB}} \\
\end{array}$ & $\begin{array}{r}4.54 \\
\pm 0.00^{\mathrm{bA}} \\
\end{array}$ & $\begin{array}{r}71.39 \\
\pm 0.01^{\mathrm{ab}} \\
\end{array}$ & $\begin{array}{r}1.51 \\
\pm 0.00^{\mathrm{bB}} \\
\end{array}$ & $\begin{array}{r}11.18 \\
\pm 0.01^{\mathrm{aB}} \\
\end{array}$ & $\begin{array}{r}11.28 \\
\pm 0.01^{\mathrm{aB}} \\
\end{array}$ & $\begin{array}{r}82.32 \\
\pm 0.01^{\mathrm{ab}} \\
\end{array}$ & $\begin{array}{r}23.12 \\
\pm 0.01^{\mathrm{bB}}\end{array}$ \\
\hline B50 & $\begin{array}{r}21.40 \\
\pm 0.40^{\mathrm{bB}} \\
\end{array}$ & $\begin{array}{r}4.61 \\
\pm 0.00^{\mathrm{bA}} \\
\end{array}$ & $\begin{array}{r}65.41 \\
\pm 0.01^{\mathrm{aA}} \\
\end{array}$ & $\begin{array}{r}2.08 \\
\pm 0.02^{\mathrm{bC}} \\
\end{array}$ & $\begin{array}{r}12.96 \\
\pm 0.01^{\mathrm{ac}} \\
\end{array}$ & $\begin{array}{r}13.12 \\
\pm 0.00^{\mathrm{ac}}\end{array}$ & $\begin{array}{r}80.87 \\
\pm 0.09^{\mathrm{aA}} \\
\end{array}$ & $\begin{array}{r}29.26 \\
\pm 0.01^{\mathrm{bc}}\end{array}$ \\
\hline G10 & $\begin{array}{r}21.30 \\
\pm 0.21^{\mathrm{aA}}\end{array}$ & $\begin{array}{r}4.37 \\
\pm 0.00^{\mathrm{aA}}\end{array}$ & $\begin{array}{r}89.77 \\
\pm 0.00^{\mathrm{bC}}\end{array}$ & $\begin{array}{r}-0.62 \\
\pm 0.01^{\mathrm{aA}}\end{array}$ & $\begin{array}{r}13.65 \\
\pm 0.00^{\mathrm{bA}}\end{array}$ & $\begin{array}{r}13.67 \\
\pm 0.00^{\mathrm{bA}}\end{array}$ & $\begin{array}{r}92.57 \\
\pm 0.05^{\mathrm{bC}}\end{array}$ & $\begin{array}{r}5.86 \\
\pm 0.00^{\mathrm{aA}}\end{array}$ \\
\hline G30 & $\begin{array}{r}21.31 \\
\pm 0.30^{\mathrm{aAB}}\end{array}$ & $\begin{array}{r}4.32 \\
\pm 0.00^{\mathrm{aA}}\end{array}$ & $\begin{array}{r}85.62 \\
\pm 0.01^{\mathrm{bB}}\end{array}$ & $\begin{array}{r}-0.38 \\
\pm 0.01^{\mathrm{aB}}\end{array}$ & $\begin{array}{r}18.35 \\
\pm 0.00^{\mathrm{bB}}\end{array}$ & $\begin{array}{r}18.36 \\
\pm 0.00^{\mathrm{bB}}\end{array}$ & $\begin{array}{r}91.17 \\
\pm 0.04^{\mathrm{bB}}\end{array}$ & $\begin{array}{r}12.08 \\
\pm 0.00^{\mathrm{aB}}\end{array}$ \\
\hline G50 & $\begin{array}{r}21.31 \\
\pm 0.27^{\mathrm{aB}}\end{array}$ & $\begin{array}{r}4.28 \\
\pm 0.00^{\mathrm{aA}}\end{array}$ & $\begin{array}{r}83.01 \\
\pm 0.00^{\mathrm{bA}}\end{array}$ & $\begin{array}{r}-0.09 \\
\pm 0.01^{\mathrm{ac}}\end{array}$ & $\begin{array}{r}20.79 \\
\pm 0.01^{b C}\end{array}$ & $\begin{array}{r}20.79 \\
\pm 0.01^{\mathrm{bc}}\end{array}$ & $\begin{array}{r}90.24 \\
\pm 0.04^{\mathrm{bA}}\end{array}$ & $\begin{array}{r}15.66 \\
\pm 0.00^{\mathrm{ac}}\end{array}$ \\
\hline
\end{tabular}

Different lowercase letters indicate significant difference in olive type and different uppercase letters indicate significant difference in olive content between samples $(p \leq 0.05)$. Results are expressed as mean value $\pm S D$.

TS=total solids

Colour measurement of all samples was performed by colorimetric analysis and recorded values $\left(L^{*}, a^{*}, b^{*}\right)$, as well as calculated ones $\left(C^{*}, H^{\circ}, \Delta E^{*}{ }_{a b}\right)$, are presented in Table 1 and 2. Considering raw materials (Table 1), FC was described by a bright, slightly green colour with yellow component $\left(L^{*}=\right.$ 94.35, $\left.a^{*}=-1.05, b^{*}=10.02\right)$ and moderate saturation $\left(C^{*}=10.07\right)$ in yellow area $\left(H^{\circ}=95.95\right)$. Similar fresh cheese colour data reported Evert-Arriagada et al. (2012). On the other hand, B samples were instrumentally defined by a darker colour in slightly red and yellow area $\left(L^{*}=19.55, a^{*}=3.70, b^{*}=6.30\right)$, while $G$ had moderate redness luminosity combined with expressed yellowness $\left(L^{*}=57.61, a^{*}=4.12\right.$, $\left.b^{*}=34.73\right)$. The obtained results are generally in accordance with data presented in Ghorbal et al. (2018) study of Gemlik olives during ripening at several locations. According to the calculated $\mathrm{C}^{*}$ and $\mathrm{H}^{\circ}$ values, colour tone of $\mathrm{B}$ was in a dark deep yellow area $\left(C^{*}=7.30, H^{\circ}=59.53\right)$ and $G$ was located in a dull middle yellow area $\left(C^{*}=34.98, H^{\circ}=83.24\right)$. Addition of $B$ and $G$ different contents into FC significantly $(p \leq 0.05)$ affected all colour parameters of SCO (Table 2). BSCO samples were darker regarding GSCO, what is in accordance with B and $\mathrm{G}$ lightness. $L^{*}$ values of BSCO ranged from 65.41-78.96 and in GSCO they were in 83.01-89.77 range. The increase of olives addition resulted with the lightness decrease in SCO of both olive types, where samples with the highest olives content were the darkest $(B 50=65.41, G 50=83.01)$. As can be seen, $L^{*}$ strongly correlated with TS and high correlation was established with $\mathrm{pH}$ value (Table 4). Observing the $a^{*}$ parameter, BSCO samples were characterized by low positive $a^{*}$ values $(1.21-2.08)$, belonging to the red colour area, while GSCO samples had low, but negative $a^{*}$ values $(-0.09--0.62)$, meaning transit to greenness. Increasing of the olives content caused the increase of $a^{*}$ values in SCO of both olive types (Table 2), where $a^{*}$ showed strong correlation with $\mathrm{TS}$, pH value and $L^{*}$ (Table 4). Regarding $b^{*}$ values, all SCO samples were situated in yellow colour area (positive $b^{*}$ values), with $b^{*}$ in range from 9.8920.79, where all GSCO had more pronounced yellow component. As well as in trend of $a^{*}$, values of $b^{*}$ increased with the increase of olive content. The observed trends reflected also on SCO $C^{*}$ values, where BSCO samples were characterized with lower C* values (9.97-13.12) opposite to GSCO samples (13.67-20.79), defining GSCO colour as more clear. As previously, $C^{*}$ values increased by the greater addition of the olives, meaning olives addition gave 
TABLE 4. Correlation coefficients between examined parameters of spreadable cheese fortified with olives

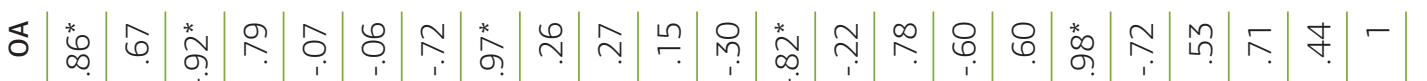

ル

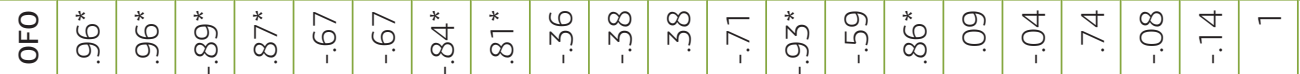

৪

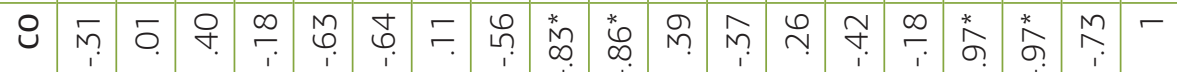

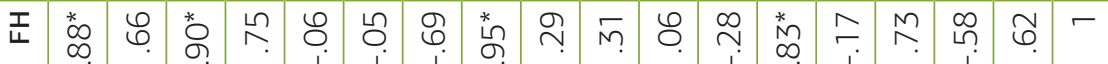

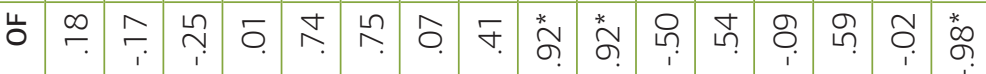

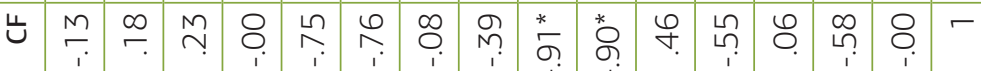

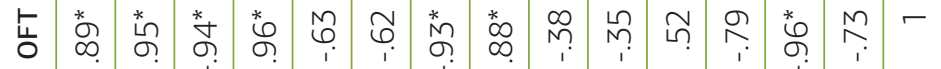

の

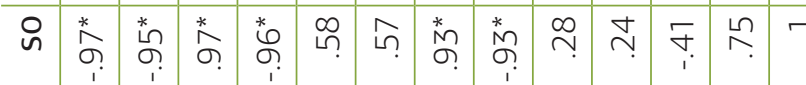

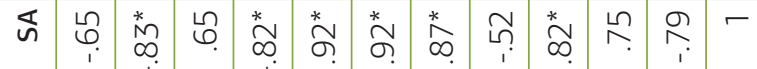

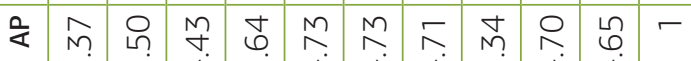

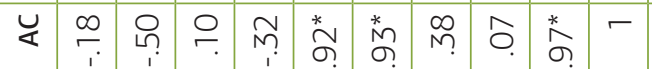

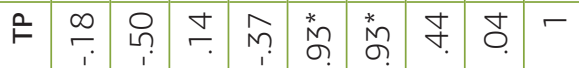

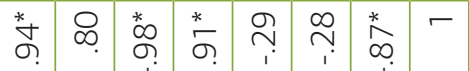

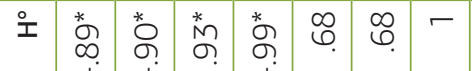

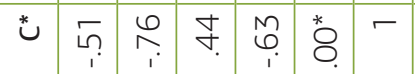

* กิ

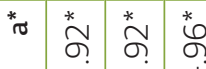

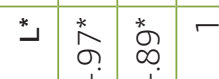

I $\stackrel{*}{\sim}$

乞

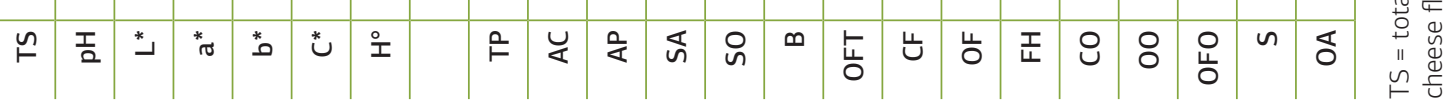


more saturated colour of SCO. Moreover, $\mathrm{C}^{*}$ strongly correlated with $b^{*}(r=1.00)$. Presented $H^{\circ}$ values explained SCO colour tone, where all samples were situated in yellow area (80.87-92.57) despite the olive type. It should be mentioned that BSCO samples had $H^{\circ}$ values from 80.87 to 83.02 , while $H^{\circ}$ of GSCO were in range from 90.24 to 92.57 . Same as with the $L^{*}$ values, the olive content increase resulted in the decrease of $\mathrm{H}^{\circ}$, but without major alterations in the area of the colour tone. In order to observe the change of SCO colour in reference to FC, total colour difference $\left(\triangle E^{*}{ }_{a b}\right)$ was calculated (Table 2$)$. Obtained results showed greater BSCO colour difference comparing to FC, contrary to GSCO, where at the same time larger amount of olive content resulted with higher $\Delta \mathrm{E}^{*}{ }_{\mathrm{ab}}$ in both olive type SCO. Expectedly, the maximum $\Delta \mathrm{E}^{*}{ }_{\mathrm{ab}}$ values peaked in SCO with the highest olive content with almost twofold difference between samples ( $\mathrm{B} 50=29.26, \mathrm{G} 50=15.66)$. Also an interesting observation could be noticed regarding the $\Delta \mathrm{E}^{*}{ }_{\text {ab }}$ values of $\mathrm{B} 10$ (15.56) and G50 (15.66) which were almost the same.

Olive is rich in polyphenols (Romero et al., 2004; Othman et al., 2009; Boskou, 2010; Malheiro et al., 2011; Durante et al., 2018; García et al., 2018; Ghorbal et al., 2018; Johnson and Mitchell, 2018; Johnson et al., 2018), which possess strong antioxidant activity, while proteins (especially casein), peptides, antioxidant enzymes (i.e. superoxide dismutase), catalase and glutathione peroxidase), conjugated linoleic acid, coenzyme Q10, lactoferrin, vitamins (C, E, A and D3), carotenoids, some minerals and some trace elements are antioxidant compounds present in various dairy products (Lindmark-Månsson and Åkesson, 2000; Barać et al., 2017; Grażyna et al., 2017). Thereby, creamy fresh cheeses generally have higher antioxidant activity, which can be related to their high levels of protein (Fardet and Rock, 2018). Hence, TP and AC determination was conducted in all samples. Table 1 provides TP and AC results of raw materials. The lowest TP content was determined in FC $(5.84 \mathrm{mg}$ $\mathrm{GAE} / 100 \mathrm{~g})$. The obtained value is in range with Apostolidis et al. (2007) TP results of various cheese types, but lower compared to other studies (Rashidinejad et al., 2013; Lucera et al., 2018; Přikryl et al., 2018), what is explainable due to different type of researched cheese, as well as differences in the extraction procedure. TP levels in olives were much higher, whereby the highest contents (43.16 mg GAE/100 g) were observed in sample G, while B showed a threefold lower TP concentration (14.78 mg GAE/100 g). Romero et al. (2004) reported similar TP concentrations in the examined green and black olives, as well as García et al. (2018) documented higher polyphenols content in green olives compared to black ones. Other studies (Othman et al., 2009; Boskou, 2010; Malheiro et al., 2011; Durante et al., 2018) showed higher polyphenol concentrations, probably caused by different extraction and determination procedure. The same trend in $\mathrm{AC}$ values among the raw materials samples can be noticed, where G peaked out with $736.93 \mu \mathrm{mol}$ $\mathrm{Fe}^{2+} / 100 \mathrm{~g}$, followed by B (237.42 $\left.\mu \mathrm{mol} \mathrm{Fe} \mathrm{Fe}^{2+} / 100 \mathrm{~g}\right)$, while FC showed the lowest AC value $(26.41 \mu \mathrm{mol}$ $\left.\mathrm{Fe}^{2+} / 100 \mathrm{~g}\right)$. Lucera et al. (2018) reported a slightly higher FRAP value in the control cheese sample, what could be due to differences in extraction methods. Other studies (Apostolidis et al., 2007; Gupta et al., 2009; Rashidinejad et al., 2013; Přikryl et al., 2018) also reported AC of cheese samples, but it is difficult to compare it with our results, as they used different cheese samples, as well as extraction and determination methods. As for olive type AC differences, Boskou (2010) noticed also higher $A C$ in green olives compared to black type. Furthermore, SCO samples significantly $(p \leq 0.05)$ differed in TP and AC regard to olive type and olive content. As presented in Figure 1, TP of BSCO samples ranged from 7.75-12.81 mg GAE/100 g and TP determined in GSCO were in 10.96-17.36 mg GAE/100 g range. The same as with TP content of B and G, GSCO showed higher TP amounts than BSCO. Besides, TP increased with the increase of olive content, resulting with the highest TP levels in B50 and G50. Considering AC, obtained results showed greater $A C$ of GSCO samples (106.19-316.96 $\mu \mathrm{mol} \mathrm{Fe} \mathrm{F}^{2+} / 100 \mathrm{~g}$ ) than BSCO (71.80-191.61 $\left.\mu \mathrm{mol} \mathrm{Fe} \mathrm{F}^{2+} / 100 \mathrm{~g}\right)$, where the highest values were obtained in samples with the highest olive content (B50, G50). It is understandable, since AC derives mainly from polyphenols present in olives and obtained values are in accordance with TP differences between B and G, as well as BSCO and GSCO. Strong correlation coefficient confirmed the relationship between TP and AC $(r=0.97)$. Based on TP and AC results, it can be concluded that the addition of olives surely contributes to spreadable cheese enrichment and thereby enhances its potential as a functional food. 


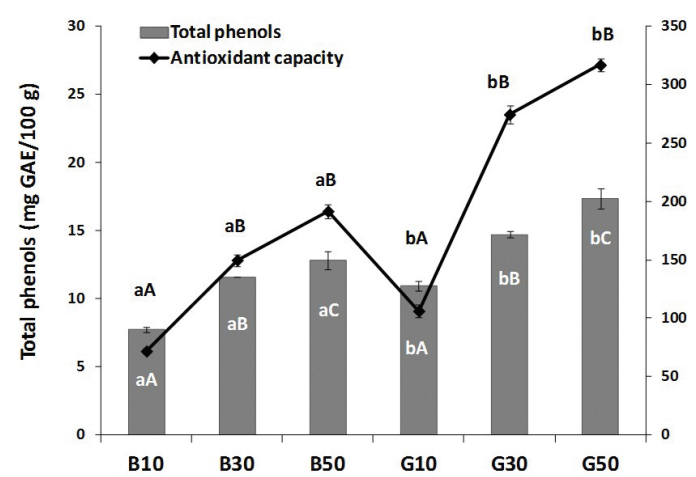

Different lowercase letters indicate significant difference in olive type and different uppercase letters indicate significant difference in olive content between samples $(p \leq 0.05)$. Results are expressed as mean value \pm SD.

FIGURE 1. Content of total phenols (mg GAE/100 g) and antioxidant capacity ( $\mu \mathrm{mol} \mathrm{Fe}^{2+} / 100 \mathrm{~g}$ ) of olive-fortified spreadable cheese
TABLE 3. F-distribution and the p-level in the ANOVA analysis of olive-fortified spreadable cheese sensory attributes with olive type and content

\begin{tabular}{l|l|l}
\hline $\begin{array}{l}\text { Sensory } \\
\text { attribute }\end{array}$ & $\begin{array}{l}\text { Olive } \\
\text { type }\end{array}$ & $\begin{array}{l}\text { Olive } \\
\text { content }\end{array}$ \\
\hline Appearance & 0.63 & 0.10 \\
\hline Saltiness & $11.45^{*}$ & 0.61 \\
\hline Sourness & $10.67^{*}$ & 0.87 \\
\hline Bitterness & $4.84^{*}$ & 0.43 \\
\hline Off-taste & 0.08 & 0.01 \\
\hline Cheese flavour & 1.84 & $11.48^{*}$ \\
\hline Olive flavour & 2.62 & $18.64^{*}$ \\
\hline Flavour harmony & 1.92 & 2.06 \\
\hline Cheese odour & 0.29 & $17.62^{*}$ \\
\hline Olive odour & $4.07^{*}$ & $17.52^{*}$ \\
\hline Off-odour & 1.79 & 0.09 \\
\hline Spreadability & 0.13 & 0.07 \\
\hline Overall acceptance & $5.76^{*}$ & $5.52^{*}$ \\
\hline${ }^{*} \leq 0.05$ & &
\end{tabular}

b)

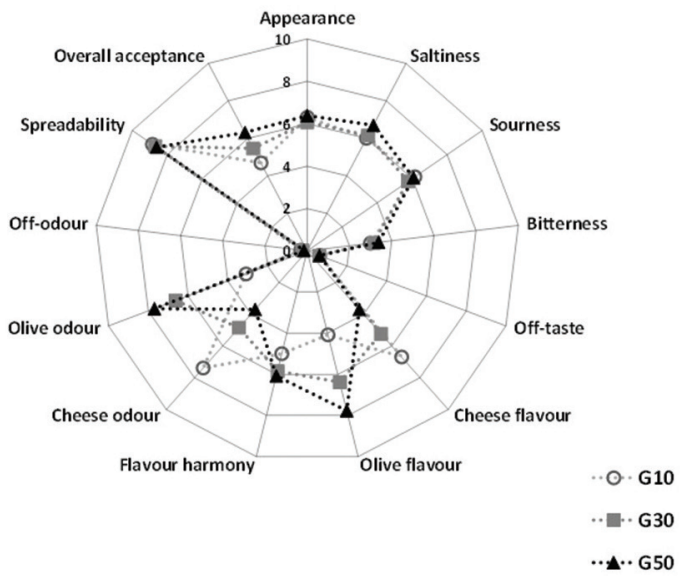

(Results are expressed as mean value)

FIGURE 2. Sensory evaluation of spreadable cheese fortified with a) black and b) green olives

Since sensory properties of the food product highly affect consumer's preference and thus their acceptability, it is of a great importance to provide the product with satisfactory and desirable characteristics. Besides that, it is necessary and essential to familiarize with the consumers opinion and demands, and their criterions about specific product surely should be investigated as well, especially when releasing a new product on the market. Thus, the prepared SCO samples were sensory evaluated using a QDA and the obtained results are presented in Figure 2, as well as the influence of olive type and olive content on the examined sensory attributes (Table 3). The results of ANOVA showed that saltiness, sourness and bitterness, olive odour and overall acceptance were significantly $(p \leq 0.05)$ affected by the olive type, while the olive content significantly $(p \leq 0.05)$ affected cheese and olive flavour, cheese and olive odour, as well as the overall acceptance. Although SCO appearance was not significantly influenced by either of the variation sources, it could be noticed that panellists scored BSCO with 
slightly higher appearance scores, whereby the sample B10 was scored with the most excellent appearance (6.9), while larger B content was not contributing to the higher appearance scores (B30 $=6.6, \mathrm{~B} 50=6.5$ ). Opposite to that, GSCO with the highest olive content was the most attractive (G50 = 6.4) and other two GSCO samples scored slightly lowers scores for the same attribute $(\mathrm{G} 10=6.3$, $\mathrm{G} 30=6.1$ ). Compared to the instrumentally defined colour results, it could be concluded that panellists preferred SCO with darker and less yellow colour, where $L^{*}$ value strongly correlated with overall acceptance $(r=-0.92)$ also. According to the evaluated taste properties, SCO differed by its dominant taste attributes (saltiness, sourness, bitterness). GSCO showed a more pronounced saltiness, sourness and bitterness (saltiness 6.0-6.7, sourness 5.8-6.2, bitterness 3.0-3.4), unlike the BSCO (saltiness 4.4-4.9, sourness 4.0-5.2, bitterness 1.6-2.3), whereby a larger olive content in SCO of both olive types resulted with stronger expression of saltiness and bitterness. BSCO sourness decreased with increase of olive amount, while GSCO generally retained its sourness despite various olive contents. These panellists' observations corresponded with the determined $\mathrm{pH}$ values of raw materials as well as SCO samples, where obviously in SCO with the lowest olive content of both olive types, sourness was mainly provided from FC. The increase of B, which had a higher $\mathrm{pH}$ value, decreased the sour sensation in SCO, while GSCO samples kept sourness expression regardless of the olive content, due to the $\mathrm{G}$ content, which $\mathrm{pH}$ value was lower in the start. A strong correlation coefficient between sourness and $\mathrm{pH}$ demonstrated the above observations (Table 4). The olive bitter taste originates mainly from oleuropein - the major polyphenol in olives, and ligstroside, that hydrolyse and form bitterless components hydroxytyrosol and tyrosol (Johnson and Mitchell, 2018; Johnson et al., 2018). As oleuropein content decreases due to ripening (Ghorbal et al., 2018; Johnson and Mitchell, 2018) or processing (García et al., 2018), green olives are characterized by a more pronounced bitter taste compared to black olives (Johnson and Mitchell, 2018). Accordingly, GSCO were scored as more bitter and its bitterness increased with the addition of olives. Additionally, a strong correlation between bitterness and TP $(r=0.84)$ was observed. Flavour of the SCO was evaluated with two main attributes, cheese and olive flavour. According to the sensory scores, cheese flavour was slightly more noticeable in all BSCO and its expression decreased in both olive types SCO with the increase of olive content. Differently, olive flavour was more dominant among the GSCO and it was more pronounced with the olive content increase. Considering flavour harmony, better scores were found in BSCO (5.5-7.2), than in GSCO (5.0-6.1). Higher BSCO harmony scores are probably related with its lower saltiness, sourness and bitterness expression. Based on the panelists scoring, it can also be assumed that less expressed olive flavour is more suitable for achieving better flavour harmony. SCO odour evaluation was also divided by two main attributes, cheese odour and olive odour. As with sensory results of cheese and olive flavour, cheese and olive odour intensity were equally recognized, meaning cheese odour was more present among BSCO and its intensity decreased with the increase of added olives despite the olive type, while GSCO had more intensive olive odour which increased with addition of olives in SCO of both olive types. Off-taste and off-odour, representing undesirable SCO attributes, were not remarkably perceived by the panellists regardless of the olive type or olive content. Spreadability of SCO was also evaluated by the panellists, since spreadability is an important characteristic of spreadable cheese. Its sensory scores, ranging from 8.6-9.1, evidenced a very good possession of spreadability in all SCO samples, whereby the highest score was achieved in B50. The last sensory attribute for which panellists were asked to evaluate was the overall acceptance. Based on their preference, they preferred $\mathrm{BSCO}(\mathrm{B} 10=5.5, \mathrm{~B} 30=6.7, \mathrm{~B} 50=7.8)$ in comparison to GSCO (G10 = 4.7, G30 = 5.5, G50 = 6.3), as well as they favoured the SCO of both olive types containing the highest olive amount where B50 surely distinguished as the highest scored. Based on the correlations, it seems that scores for overall acceptance were most affected by sourness $(r=-0.82)$ and more flavour harmony contributed to overall acceptance $(r=0.98)$.

Finally, PCA was applied to examine a possible grouping of SCO samples by the determined physical, chemical and sensory properties influenced by olive type and olive content. The obtained PCA results are shown in Figure 3, where the first two 


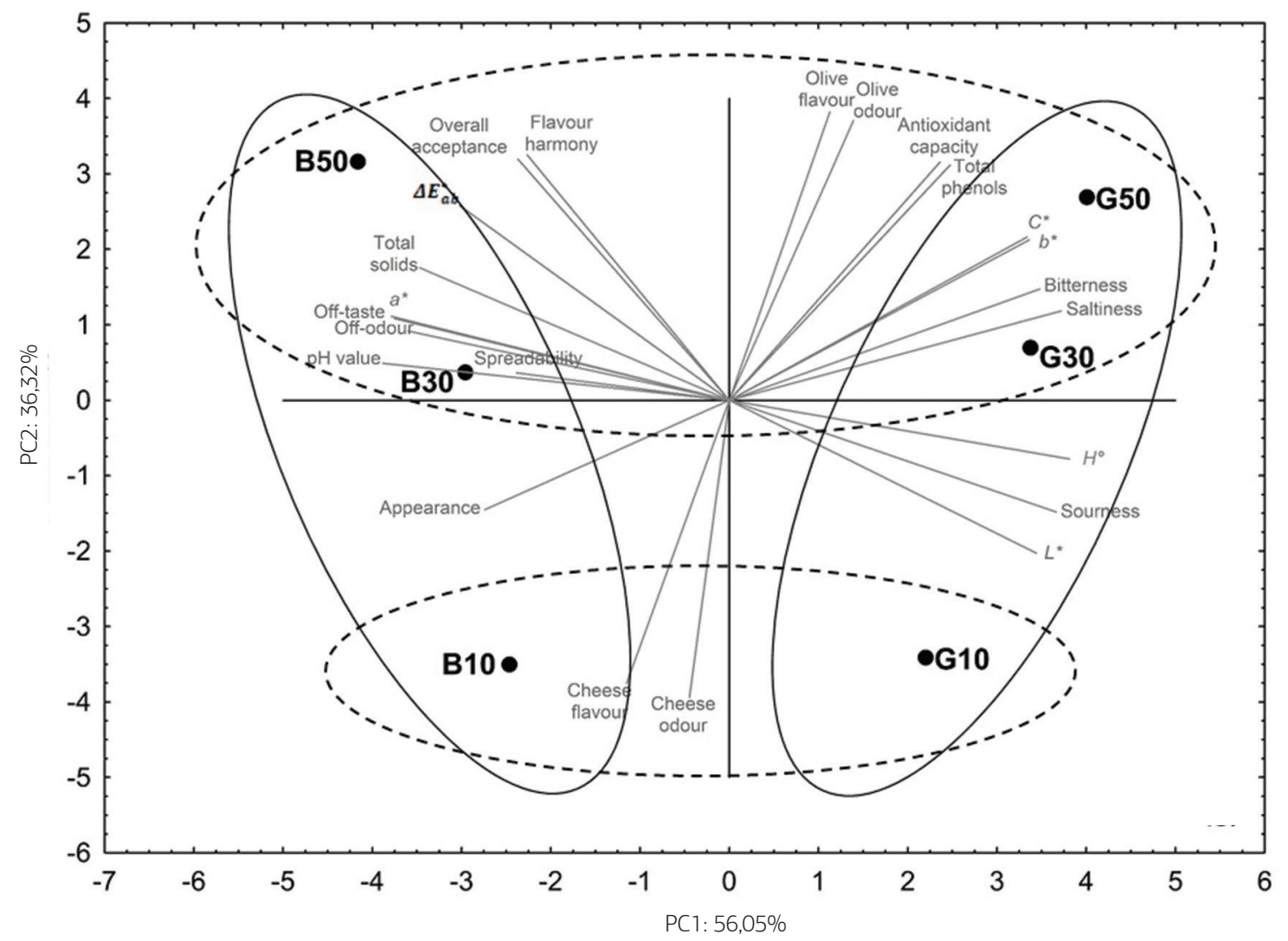

$\mathrm{B}=$ black olives, $\mathrm{G}=$ green olives

$10,20,30$ = olive content $(\mathrm{g})$

FIGURE 3. Distribution of olive-fortified spreadable cheese samples in two dimensional coordinate system defined by the first two principal components (PC1 and PC2) according to the investigated influences: olive type (black, green) and olive content (10, 30, 50 g)

components (PC1, PC2) explained $92.37 \%$ of the total variance and the apparent separation of SCO could be observed. Considering the olive type, all BSCO samples situated on the left side of the plot and all GSCO samples located on its right side, where the most discriminating variables were $L^{*}$, $b^{*}, C^{*}, \Delta E^{*}{ }_{a b}$, TP, AC, cheese and olive flavour, flavour harmony, cheese and olive odour, and overall acceptance, since they strongly correlated with PC2. Furthermore, all SCO samples with the lowest olive amount (B10, G10) placed below PC1, while SCO with higher content of olives (B30, G30, B50, G50) grouped above the PC1. TS, pH value, $L^{*}, a^{*}, b^{*}, C^{*}$, $H^{\circ}, \Delta E^{*}{ }_{a b}, T P, A C$, appearance, saltiness, sourness, bitterness and off-taste, flavour harmony, off-odour, spreadability and overall acceptance strongly correlated with $P C 1$, and thereby represent the most important differentiating variables. PCA results are in accordance with previously explained results in Table 2, Figures 1 and 2.

\section{Conclusions}

After the conducted study, it could be concluded that spreadable cheese fortified with olives has good potential as a functional product with desirable and favourable sensory characteristics that can satisfy consumer's demands. Spreadable cheeses with both olive types showed promising characteristics, whereby black olives samples received slightly better preference, indicating the importance of the appropriate olive type selection, as well as its proportion. However, both types of olive fortified spreadable cheeses could fulfil consumer's criterions and consequently have market potential. 


\section{Funkcionalna i senzorska svojstva sirnog namaza obogaćenog maslinama}

\section{Sažetak}

Cilj ovog rada bio je ispitati utjecaj tipa (crne i zelene) i udjela masline na kvalitetu i senzorska svojstva sirnog namaza s maslinama. U uzorcima polaznih sirovina te pripremljenog sirnog namaza s maslinama određeni su ukupna suha tvar, pH vrijednost, boja (kolorimetrijski), sadržaj ukupnih fenola Folin-Ciocalteau metodom i antioksidacijski kapacitet (FRAP). Nadalje, uzorci sirnog namaza senzorski su ocijenjeni kvantitativnom deskriptivnom analizom (QDA). ANOVA je pokazala da su primijenjeni izvori varijacija značajno utjecali na većinu ispitivanih parametara. Uzorci s crnim maslinama imali su nešto viši udio suhe tvari, pH vrijednost te tamniju i zasićeniju boju. Određeni sadržaj ukupnih fenola i antioksidacijski kapacitet ukazuju na dobar potencijal sirnog namaza s maslinama kao funkcionalne hrane, gdje su uzorci sa zelenim maslinama sadržavali više ukupnih fenola i antioksidacijski kapacitet. Općenito, senzorska svojstva svih uzoraka su vrlo dobro ocijenjena, što upućuje na njihovu dobru prihvatljivost kod potrošača. Uzorci s crnim maslinama postigli su više ocjene za harmoničnost arome i ukupnu prihvatljivost, gdje se uzorak sirnog namaza s najvišim udjelom maslina istaknuo najvišim ocjenama za navedena svojstva.

\section{Ključne riječi: sirni namaz, masline, kvaliteta, fenoli, senzorska svojstva}

\section{References}

1. Alexandraki, V., Georgalaki, M., Papadimitriou, K., Anastasiou, R., Zoumpopoulou, G., Chatzipavlidis, I., Papadelli, M., Vallis, N., Moschochoritis, K., Tsakalidou, E. (2014): Determination of triterpenic acids in natural and alkaline-treated Greek table olives throughout the fermentation process. LWT-Food Science and Technology 58 (2), 609-613. https://doi.org/10.1016/j.lwt.2014.04.005

2. AOAC (1990): Official methods of analysis of the Association of Official Analytical Chemists, $15^{\text {th }}$ Ed., Volume II. Arlington, USA: Association of Official Analytical Chemists, Inc.

3. Apostolidis, E., Kwon, Y.I., Shetty, K. (2007): Inhibitory potential of herb, fruit, and fungal-enriched cheese against key enzymes linked to type 2 diabetes and hypertension. Innovative Food Science \& Emerging Technologies 8 (1), 46-54. https://doi.org/10.1016/j.ifset.2006.06.001

4. Barać, M., Pešić, M., Vučić, T., Vasić, M., Smiljanić, M. (2017): White cheeses as a potential source of bioactive peptides. Mljekarstvo 67 (1), 3-16. https://doi.org/10.15567/mljekarstvo.2017.0101

5. Benzie, I.F.F., Strain, J.J. (1996): The ferric reducing ability of plasma (FRAP) as a measure of "antioxidant power": The FRAP assay. Analytical Biochemistry 239 (1), 70-76. https://doi.org/10.1006/abio.1996.0292

6. Boskou, G. (2010): Antioxidant capacity and phenolic profile of table olives from the Greek market. In: Olives and olive oil in health and disease prevention, 925-934. https://doi.org/10.1016/B978-0-12-374420-3.00099-1

7. CIE, Commission Internationale de l'Eclairage (1976): Official recommendations on uniform colour spaces, colour differences equations and metric colour terms. Paris: France.

8. Cutrim, C.S., Cortez, M.A.S. (2018): A review on polyphenols: Classification, beneficial effects and their application in dairy products. International Journal of Dairy Technology 71 , $1-15$. https://doi.org/10.1111/1471-0307.12515

9. Durante, M., Tufariello, M., Tommasi, L., Lenucci, M. S., Bleve, G., Mita, G. (2018): Evaluation of bioactive compounds in black table olives fermented with selected microbial starters. Journal of the Science of Food and Agriculture 98 (1), 96-103. https://doi.org/10.1002/jsfa.8443

10. Estruch, R., Ros, E., Salas-Salvadó, J., Covas, M. I., Corella, D., Arós, F., Gómez-Gracia, E., Ruiz-Gutiérrez, V., Fiol, M., Lapetra, J., Lamuela-Raventos, R.M., Serra-Majem, L., Pintó, X., Basora, J., Muñoz, M.A., Sorlí, J.V., Martínez, J.A., MartínezGonzález, M.A. (2013): Primary prevention of cardiovascular disease with a Mediterranean diet. New England Journal of Medicine 368 (14), 1279-1290. https://doi.org/10.1056/NEJMoa1200303

11. Evert-Arriagada, K., Hernández-Herrero, M.M., Juan, B., Guamis, B., Trujillo, A.J. (2012): Effect of high pressure on fresh cheese shelf-life. Journal of Food Engineering 110 (2), 248-253. https://doi.org/10.1016/j.jfoodeng.2011.05.011 
12. Fardet, A., Rock, E. (2018): In vitro and in vivo antioxidant potential of milks, yoghurts, fermented milks and cheeses: a narrative review of evidence. Nutrition Research Reviews 31 (1), 52-70. https://doi.org/10.1017/S0954422417000191

13. Féart, C., Samieri, C., Alles, B., Barberger-Gateau, P. (2013): Potential benefits of adherence to the Mediterranean diet on cognitive health. Proceedings of the Nutrition Society 72 (1), 140-152. https://doi.org/10.1017/S0029665112002959

14. Frisardi, V., Panza, F., Seripa, D., Imbimbo, B.P., Vendemiale, G., Pilotto, A., Solfrizzi, V. (2010): Nutraceutical properties of Mediterranean diet and cognitive decline: possible underlying mechanisms. Journal of Alzheimer's Disease 22 (3), 715-740. https://doi.org/10.3233/JAD-2010-100942

15. García, P., Romero, C., Brenes, M. (2018): Bioactive substances in black ripe olives produced in Spain and the USA. Journal of Food Composition and Analysis 66, 193-198. https://doi.org/10.1016/j.jfca.2017.12.022

16. Ghorbal, A.B., Leventdurur, S., Agirman, B., Boyaci-Gunduz, C.P., Kelebek, H., Carsanba, E., Darici, M., Erten, H. (2018): Influence of geographic origin on agronomic traits and phenolic content of cv. Gemlik olive fruits. Journal of Food Composition and Analysis 74, 1-9. https://doi.org/10.1016/j.jfca.2018.08.004

17. Grażyna, C., Hanna, C., Adam, A., Magdalena, B. M. (2017): Natural antioxidants in milk and dairy products. International Journal of Dairy Technology 70 (2), 165-178. https://doi.org/10.1111/1471-0307.12359

18. Guinee, T.P., Pudja, P.D., Farkye, N.Y. (1993) Fresh AcidCurd Cheese Varieties. In: Cheese: Chemistry, physics and microbiology. Vol. 2. Major cheese groups. $2^{\text {nd }}$ Edition (Fox, P.F., Ed.), Dordrecht: Springer-Sience+Business Media, B. V. https://doi.org/10.1007/978-1-4615-2648-3_13

19. Gupta, A., Mann, B., Kumar, R., Sangwan, R.B. (2009): Antioxidant activity of Cheddar cheeses at different stages of ripening. International Journal of Dairy Technology 62 (3), 339-347. https://doi.org/10.1111/j.1471-0307.2009.00509.x

20. Han, J., Britten, M., St-Gelais, D., Champagne, C.P., Fustier, P., Salmieri, S., Lacroix, M. (2011): Effect of polyphenolic ingredients on physical characteristics of cheese. Food Research International 44 (1), 494-497. https://doi.org/10.1016/j.foodres.2010.10.026

21. Han, X., Shen, T., Lou, H. (2007): Dietary polyphenols and their biological significance. International Journal of Molecular Sciences 8 (9), 950-988. https://doi.org/10.3390/i8090950

22. ISO 8589 (2007): Sensory analysis: General guidance for the design of test rooms, ISO 8589, International Organization for Standardization. Geneva, Switzerland.

23. Johnson, R., Melliou, E., Zweigenbaum, J., Mitchell, A.E. (2018): Quantitation of oleuropein and related phenolics in cured Spanish-style green, California-style black ripe, and Greek-style natural fermentation olives. Journal of Agricultural and Food Chemistry 66 (9), 2121-2128. https://doi.org/10.1021/acs.jafc.7b06025

24. Johnson, R.L., Mitchell, A.E. (2018): Reducing phenolics related to bitterness in table olives. Journal of Food Quality,2018, 1-12. https://doi.org/10.1155/2018/3193185

25. Korhonen, H. (2009): Milk-derived bioactive peptides: From science to applications. Journal of Functional Foods 1 (2), 177-187. https://doi.org/10.1016/j.jff.2009.01.007

26. Lindmark-Månsson, H., Åkesson, B. (2000): Antioxidative factors in milk. British Journal of Nutrition 84 (S1), 103-110. https://doi.org/10.1017/S0007114500002324

27. Lucera, A., Costa, C., Marinelli, V., Saccotelli, M.A., Del Nobile, M.A., Conte, A. (2018): Fruit and vegetable byproducts to fortify spreadable cheese. Antioxidants (Basel, Switzerland) 7 (5), 61. https://doi.org/10.3390/antiox7050061

28. Malheiro, R., Sousa, A., Casal, S., Bento, A., Pereira, J.A. (2011): Cultivar effect on the phenolic composition and antioxidant potential of stoned table olives. Food and Chemical Toxicology 49 (2), 450-457. https://doi.org/10.1016/j.fct.2010.11.023

29. Marsilio, V., Seghetti, L., lannucci, E., Russi, F., Lanza, B., Felicioni, M. (2005): Use of a lactic acid bacteria starter culture during green olive (Olea europaea L cv Ascolana tenera) processing. Journal of the Science of Food and Agriculture 85 (7), 1084-1090. https://doi.org/10.1002/jsfa.2066

30. Othman, N.B., Roblain, D., Chammen, N., Thonart, P., Hamdi, M. (2009): Antioxidant phenolic compounds loss during the fermentation of Chétoui olives. Food Chemistry 116 (3), 662-669. https://doi.org/10.1016/j.foodchem.2009.02.084

31. Panagou, E.Z., Tassou, C.C. (2006): Changes in volatile compounds and related biochemical profile during controlled fermentation of cv. Conservolea green olives. Food Microbiology 23 (8), 738-746. https://doi.org/10.1016/j.fm.2006.02.005

32. Pérez-López, F.R., Chedraui, P., Haya, J., Cuadros, J.L. (2009): Effects of the Mediterranean diet on longevity and agerelated morbid conditions. Maturitas 64 (2), 67-79. https://doi.org/10.1016/j.maturitas.2009.07.013

33. Přikryl, J., Hájek, T., Švecová, B., Salek, R.N., Černíková, M., Červenka, L., Buňka, F. (2018): Antioxidant properties and textural characteristics of processed cheese spreads enriched with rutin or quercetin: The effect of processing conditions. LWT-Food Science and Technology 87, 266-271. https://doi.org/10.1016/j.lwt.2017.08.093

34. Rashidinejad, A., Birch, E.J., Sun-Waterhouse, D., Everett, D.W. (2013): Effects of catechin on the phenolic content and antioxidant properties of low-fat cheese. International Journal of Food Science \& Technology, 48 (12), 2448-2455. https://doi.org/10.1111/ijfs.12234

35. Revilla, I., González-Martín, M.I., Vivar-Quintana, A.M., Blanco-López, M.A., Lobos-Ortega, I.A., HernándezHierro, J.M. (2016): Antioxidant capacity of different cheeses: Affecting factors and prediction by near infrared spectroscopy. Journal of Dairy Science 99 (7), 5074-5082. https://doi.org/10.3168/jds.2015-10564

36. Romero, C., Brenes, M., Yousfi, K., García, P., García, A., Garrido, A. (2004): Effect of cultivar and processing method on the contents of polyphenols in table olives. Journal of Agricultural and Food Chemistry 52 (3), 479-484. https://doi.org/10.1021/jf030525| 
37. Romero, C., García, A., Medina, E., Ruíz-Méndez, M.V., de Castro, A., Brenes, M. (2010): Triterpenic acids in table olives. Food Chemistry 118 (3), 670-674. https://doi.org/10.1016/j.foodchem.2009.05.037

38. Romero, C., García, P., Brenes, M., García, A., Garrido, A. (2002): Phenolic compounds in natural black Spanish olive varieties. European Food Research and Technology 215 (6), 489-496.

https://doi.org/10.1007/s00217-002-0619-6

39. Shortle, E., O'Grady, M.N., Gilroy, D., Furey, A., Quinn, N.,
Kerry, J.P. (2014): Influence of extraction technique on the anti-oxidative potential of hawthorn (Crataegus monogyna) extracts in bovine muscle homogenates. Meat Science 98 (4), 828-834.

https://doi.org/10.1016/j.meatsci.2014.07.001

40. StatSoft, Inc. (2007) STATISTICA (data analysis software system), ver. 8.0., Tulsa, Oklahoma, USA. < http://www. statsoft.com/>. 